Cadernos de Clio, Curitiba, n. ${ }^{\circ}$ 4, 2013

\title{
LE GOFF, Jaques. A bolsa e a vida: a usura na Idade Média. 3 ed. São Paulo: Brasiliense, 2004.
}

Autoras: Kassia Amariz Pires ${ }^{1}$ e Natália de Medeiros Costa ${ }^{2}$

Orientadora: Adriana Mocelim de Souza Lima ${ }^{3}$

Jacques Le Goff nasceu em janeiro de 1924 em Toulon, França. Sentiu-se atraído pela história desde o colegial e cursou a École Normale Supérieure, depois a École Pratique des Hautes Études, de 1962 a 1993. É considerado um dos maiores medievalistas do mundo e pertence à velha tradição francesa que une história à geografia. Inspirado por Fernand Braudel e Maurice Lombard, tornou-se uma figura-chave da escola dos Annales por ter conseguido integrar a reflexão sobre o espaço e o tempo da dimensão humana. Escreveu diversos livros que se tornaram clássicos, impondo um novo estilo de pensar sobre a história. Em 1972, sucedeu Fernand Braudel na École des Hautes Études em Sciences Sociales e nela permaneceu até 1977, cedendo seu lugar a François Furet (LE GOFF, 2005: 1). Jacques Le Goff participou da Escola dos Annales em sua terceira geração, muito lembrada pela pluralidade, pois é nessa geração que

${ }^{1}$ Graduanda do $2^{\circ}$ ano do curso de licenciatura em História pela Pontifícia Universidade Católica do Paraná. Integrante da iniciação científica da mesma instituição, trabalhando com criação de imagem de Júlio César através de seus escritos. Orientadora: Adriana Mocelim de Souza Lima. Email: kassia.amariz@gmail.com ${ }^{2}$ Graduanda do $2^{\circ}$ ano do curso de licenciatura em História pela Pontifícia Universidade Católica do Paraná. Email: natalia.medeiroscosta@gmail.com

${ }^{3}$ Professora de História antiga e medieval da Pontifícia Universidade Católica do Paraná. Orientadora de iniciação científica com temas de construção de imagens na idade antiga e média. Email: adriana.mocelim@pucpr.br 
ocorre a entrada de mulheres historiadoras, como Christiane Klapisch e Arlette Farge, por exemplo (BURKE, 1991: 56-57).

No livro “A Bolsa e a Vida”, Le Goff debruça novamente sobre a época medieval, dessa vez concentrando-se no fenômeno da usura. A usura pode ser considerada um dos grandes problemas do século XIII. A irrupção e difusão da economia monetária ameaçava os velhos valores cristãos. Um novo sistema econômico estava a ponto de se formar. Para sua arrancada inicial, era necessário o intenso uso de práticas até então condenadas pela Igreja. Como poderia uma religião que opõe tradicionalmente Deus e o dinheiro justificar a riqueza? Numa perspectiva de longa duração, Le Goff reconhece no usurário a qualidade de precursor de um novo sistema econômico: o capitalismo.

"Uma andorinha não faz verão. Um usurário não faz o capitalismo. Mas um sistema econômico substitui um outro apenas no final de uma longa corrida de obstáculos de todas as espécies. A história são os homens. Os iniciadores do capitalismo são os usurários, mercadores do futuro, mercadores do tempo que, desde o século XV, Leon Battista Alberti definirá como do dinheiro” (LE GOFF, 2004: 91).

O historiador Jacques Le Goff pretende em "A Bolsa e a Vida” mostrar como um obstáculo ideológico pode travar, ou retardar, a criação de um sistema econômico diferente, que, como ele acredita, seja possível compreender melhor perscrutando os homens. Para tanto, o livro traz os conceitos de usura e como ela era vista durante o século XIII. Apresenta diversos bispos, teólogos, filósofos, poetas que escreveram sobre a usura como forma de abordar o quanto sua ação era contra as leis de Deus. A 


\section{Cadernos de Clio, Curitiba, n. ${ }^{\circ}$ 4, 2013}

posição da sagrada escritura sobre a usura está essencialmente em cinco textos, sendo quatro deles pertencentes ao Antigo Testamento (LEVÍTICO apud LE GOFF, 2004: 17)

Se o teu irmão que vive contigo achar-se em dificuldade e não tiver com que te pagar, tu o sustentarás como a um estrangeiro ou hóspede, e ele viverá contigo. Não tomarás dele nem juros, nem usuras, mas terá o temor do teu Deus, e que o teu irmão viva contigo. Não lhe emprestarás dinheiro a juros, nem lhe darás alimento para receber usura (Levítico, XXV, 35-37).

Outra referência empregada pelo autor, que trabalha a questão da usura, é Dante Alighieri em sua obra “A Divina Comédia.” Dante posiciona em seu Inferno os usurários junto aos sodomitas, conhecidos por pecarem contra a natureza.

e pois no menor giro vão penando

os filhos de Caorsa (caorsinos = usurários)

e de Sodoma

e os que vivem contra Deus clamando

(DANTE apud LE GOFF, mando 2004: 48).

Por fim Jacques Le Goff referencia Jacques de Vitry. Em seu sermão modelo ad status 59, descreve de maneira interessante a relação que tem a usura com Satã, afirmando que esta profissão foge à natureza criada por Deus (sociedade trifuncional).

Deus ordenou três categorias de homens, os camponeses e outros trabalhadores para assegurar a subsistência dos outros, os cavaleiros para defende-los, os clérigos para governa-los, mas o Diabo ordenou uma quarta, os usurários. Estes não participam do trabalho 


\section{Cadernos de Clio, Curitiba, n. ${ }^{\circ}$ 4, 2013}

dos homens e não serão castigados com os homens, mas com os demônios (VITRY apud LE GOFF, 2004: 54).

Bastante renegado durante este período, o ato da usura era considerado mais do que um crime, um pecado. A mentalidade neste período da história é fortemente ligada aos valores pregados pela Igreja, por isto, o ato de usura era tão condenável. Diversos documentos foram escritos demonstrando a pecaminosa ação de usurar. Descreviam o pecado da usura ou apresentavam histórias de pessoas que se transformaram em usurários, a fim de obter ganhos próprios.

O primeiro capítulo "Entre o dinheiro e o Inferno: a usura e o usurário” apresenta o contexto sobre a usura. Considerada como impulso inicial do capitalismo comentado por Le Goff (2004: 5) no trecho “a formidável polêmica em torno da usura constitui de certo modo o parto do capitalismo” a usura foi um dos grandes problemas do século XIII. Aponta sobre as justificativas da igreja a respeito da prática da usura, demonstrando a concepção de pecado e penitência que mudou profundamente durante os séculos XI a XIII. O usurário aparece como protagonista de vários documentos. Um dos documentos citados por Le Goff “Os exempla” eram histórias curtas, fáceis de serem lembradas, tidas como verídicas para serem inseridas nos sermões, comuns na época. Tudo isto para trazer a resposta para os problemas, para entregar a chave do paraíso se compreendida.

No segundo capítulo “A bolsa: a usura” Le Goff comenta de forma minuciosa sobre várias fontes documentais que trazem o conceito da usura. Coloca que a usura é "arrecadação de juros por um emprestador nas operações que não devem dar lugar ao juro” (LE GOFF, 2004: 14). De- 
monstra que as práticas de usura só eram aceitas contra o adversário em guerra ou entre judeus e cristãos, mas nunca o contrário. Apresenta diversos personagens que incluíram em decretos sobre a prática da usura, passagens de Bispos sobre a rejeição do paraíso ao usurário, a proibição da usura entre clérigos e laicos e ainda a visão de cônegos que consideraram o usurário como ocioso. A ociosidade era vista como a mãe de todos os vícios. Papas e grandes filósofos deram sua palavra sobre usura e acabaram por decretar que mais do que um crime, era um pecado e o usurário iria para inferno.

No terceiro capítulo “O ladrão de tempo” apresenta a ideia de bolsa e tempo. O homem da bolsa seria o usurário e esta bolsa seria cheia de moedas, dinheiro. O tempo pertence a Deus. Há alguns comentários sobre a ligação do judeu com usurário, já citados anteriormente pela possibilidade de judeus cometerem usura e não o contrário. Porém, com a mudança no século XII houve um impulso econômico, gerando um crescimento enorme da circulação monetária e no desenvolvimento do crédito, houve o aparecimento de usurários cristãos. A Igreja apresentava os usurários como piores que judeus, pois os judeus não cometiam a usura entre os irmãos. Como nos outros capítulos, Le Goff apresenta vários trechos de obras da época que condenavam a usura. Finaliza abordando o perigo em ser amigo de um usurário, pois este seria tão pecador quanto aquele.

No quarto capítulo, '’O usurário e a morte’’, Le Goff primeiramente apresenta a ideia de que a profissão do usurário é considerada a mais pecaminosa dentre todas as profissões com essa conotação. No século XIII, devido ao novo sistema teórico, a escolástica, essas profissões foram divididas entre aquelas que realmente eram ilícitas daquelas que o eram 
por acidente. A profissão da usura permanece, durante o século XIII, pecaminosa, não cabendo argumentos para desculpá-la. Le Goff, então, apresenta o usurário como parceiro terreno do Diabo, até que chega o leito de morte e com ela o desejo do Diabo de possuir mais uma alma. Para que isso seja possível, Satã usa de artimanhas para evitar a confissão e a restituição do dinheiro roubado, mandando, assim, a alma para o inferno.

No quinto capítulo, ‘'a bolsa e a vida: o Purgatório’’, o autor inicia voltando ao ano mil, para trabalhar as mudanças pelas quais passou a sociedade nessa época. Se inicia o período chamado de feudalismo, onde as desigualdade se atenuam, mas a população encontra um situação um pouco melhor do que a registrada anteriormente. Em um primeiro momento, o usurário continuou a ser excluído e discriminado como pecador. Em seguida, nota-se que a usura passa a ser vista mais brandamente e o usurário não seria, em todos os casos, mandado diretamente ao Inferno. Le Goff descreve que haveria duas vias que conduziriam à aceitação do usurário: “...a moderação na prática e a aparição de novos valores no domínio das atividades econômicas” (LE GOFF, 2004: 68). Isso indica que a usura não era por completo pecaminosa, o que era considerado pecado era a taxa que ultrapassava a taxa de juros determinada. Com isso chegamos a ideia de Purgatório, criado em um período em que a Igreja já não mais podia sustentar a ideia que havia apenas o Paraíso e o Inferno. O usurário moderado, então, poderia se livrar do destino de ser mandado ao Inferno, para se redimir de seus pecados no Purgatório e ascender, assim, ao céu.

No sexto e último capítulo, intitulado “o coração também tem suas lágrimas”, o autor trabalha acerca da remissão dos pecados dos usurários. Para ascender ao Paraíso, o usurário deveria cumprir três passos: a confis- 
são, a contrição e a satisfação (por satisfação, no caso do usurário, deveremos entender a restituição de tudo que por ele fora roubado). No caso da contrição, essa não pode ser apenas composta por palavras da boca para fora, deve sair do coração do usurário, uma confissão verdadeira. Tirando raras exceções, a única esperança que tem um usurário é a de ser enviado ao Purgatório, pois, como sintetiza Le Goff: “...a esperança do Purgatório conduz à esperança do Paraíso” (LE GOFF, 2004: 91). Ao dar ao usurário uma esperança de não ser mandado ao Inferno, na forma de Purgatório, o capitalismo encontra a possibilidade de ser instalado como novo sistema econômico.

A temporalidade do texto de Le Goff baseia-se em personagens do século XII e XIII, assim como em estudiosos contemporâneos (século $\mathrm{XX)}$. Ele emprega diferentes documentos para explicar sobre a usura, como pensavam sobre este ato e de que forma a transformação monetária afetou os interesses econômicos e políticos. O texto apresenta longa duração.

Antes da construção da ideia de purgatório, o usurário iria direto para inferno. A prática da usura ficou de tal maneira comum e necessária para movimentação econômica, que a abordagem de um novo "local”, o purgatório, fez com que o usurário tivesse chances de ir para o céu, já que o purgatório seria o local que poderia "limpar” seus pecados. O autor retrata a usura como um elemento chave na mudança da mentalidade do baixo medievo, cada vez mais era premente a necessidade de tolerar o usurário, em função das transformações econômicas que se verificava na sociedade. Le Goff soube retratar a usura na Idade Média de forma simples e direta. A utilização de documentos oficiais, summas, exempla, as 


\section{Cadernos de Clio, Curitiba, n. ${ }^{\circ}$ 4, 2013}

narrativas de confessores, servem para dar respaldo ao seu trabalho, melhor definindo o que era a prática de usura na Idade Média.

\section{Referências}

BURKE, Peter. A Revolução Francesa na Historiografia: a Escola dos Annales 1929 - 1989. São Paulo: Editora Universidade Estadual Paulista, 1991.

LE GOFF, Jaques. A bolsa e a vida: a usura na Idade Média. 3 ed. São Paulo: Brasiliense, 2004.

LE GOFF, Jaques. A civilização do Ocidente Medieval. Bauru: Edusc, 2005. 